74. A. O. D. Moga. "The Flora of Vryburg District in Relation to the Geology."

75. A. O. D. MogG. "A Preliminary Account of the Flora of Pretoria in Relation to the Geology."

76. G. GürICr. " Die bislang-ältesten Spuren von Organismen in Südafrika."

77. R. HEINz. "Die Kreide-Inoceramen der Südafrikanischen Union."

78. A. Timmerhans. "La Géologie Générale du Haut Katanga." [Abstract.]

\title{
CORRESPONDENCE.
}

\section{THE APPLICATION OF MECHANICAL ANALYSIS TO GEOLOGICAL MAPPING.}

SIR,-As the authors of the paper under the above title we have noticed, with interest, Mr. F. Gossling's letter in the February issue of the Geological Magazine. We have not questioned the accuracy of his observations in the area mapped by him, nor do we admit making the erroneous assumptions he attributed to us.

He states that "the distinctions drawn later in the [his] paper between the major divisions as wholes emerged from a comparative study of the whole series of curves". We applied the method of mechanical analysis, in the first place, in an endeavour to distinguish the main divisions of the Lower Greensand, in a certain area, near Dorking, where the lithology is similar from top or bottom. The outcome of our work was to show that, not only were the results of no value for that purpose, but that the comparison of grade curves of sediments from unknown horizons, within the lower Greensand, might be very misleading if used as a basis for correlation.

We have again read through Mr. Gossling's paper and can find no evidence that the method has proved decisive in the solution of any doubtful stratigraphical points: furthermore his minor subdivisions may be identified in the field.

H. G. Dines.

F. H. Edmunds.

\section{GEOLOGICAL GYRATIONS.}

SIR,-Y Your reviewer of The Modern Dowser seems to have missed a point of some interest to geologists, especially those dealing with the subject of water-supply. This book, issued at a moderate price and stretching credulity to its extreme limit, is certainly destined to become popular among the masses. Let us note, therefore, that its author is careful to mention, p. 52, the importance of geological study, especially of the region where the dowser is working. May we, perhaps, suspect that the divining gyrations of his own pendulum are not free from a bias due to shrewd deductions from geological observations?

G. W. Grabiram. 